\title{
Development of Chemistry Practical Guide Book Innovative on General Chemistry Integrated Problem Based Learning Models
}

\author{
Rhindra Pahlawan \\ Chemistry Education of Post graduate \\ Universitas Negeri Medan \\ Indonesia \\ email: rhindrapahlawan16@gmail.com
}

\author{
Ramlan Silaban \\ Lecturer in Chemistry Education of Post \\ graduate \\ Universitas Negeri Medan \\ Indonesia
}

\author{
Ida Duma Riris \\ Lecturer in Chemistry Education of Post \\ graduate \\ Universitas Negeri Medan \\ Indonesia
}

\begin{abstract}
This study aims to obtain an innovative on general chemistry lab guide for agrotechnology study programs. The research was a development research referring to the ADDIE model (Analysis, Design, Development, Implementation, and Evaluation). Practical guidebooks were arranged following the steps of the learning model based on Problem Based Learning. Research locations in the Chemistry Laboratory, Faculty of Agriculture, Agrotechnology Study Program, Medan Area University. The results showed that the validation of basic chemistry practicum guidebooks that had been developed in general showed an average value of 3.90 meaning very valid and did not need to be revised and was very feasible to use. The learning outcomes of the practitioner have an $\mathrm{N}$-gain average of 0.65 was categorized as medium. The results of the practical skills average grade value of 93.52 which is categorized very well. The results of the practical guideline assessment conducted by the practitioner after using a chemical practicum guidebook that has been developed has a percentage of $88.10 \%$ with a very good category.
\end{abstract}

Keywords: practical guide book, research and development, problem based learning

\section{INTRODUCTION}

Development research was often known as Research and Development (R \& D). Development research was a process used to develop and validate research products (Borg and Gall, 1983). Development research was also defined as a systematic study to design, develop, and evaluate programs, processes and learning outcomes that must meet the criteria of consistency and effectiveness internally [1]. In the world of education, development research was a relatively new type of research [2]. Development research in education was directed at producing products, one of the development of teaching materials.

Teached material were materials arranged systematically and display competencies that must be mastered by students, such as textbooks, worksheets, models, modules, audio teaching materials, handouts, etc. [3]. The competency approach requires the use of modules in the implementation of learning, because modules can help realize quality learning and the application of modules can also condition learning activities better planned, independent, complete and with clear results (output) [4].

The guidebook was used as part of teaching material that contains guidelines in conducting practical activities that need to be developed to create optimal practical activities in a learning process, especially in chemistry-related subjects, a guidebook more complete, structured and contains appropriate guidelines so that students can do their own lab work correctly. To prove the known chemical theory, practicum was carried out to prove the truth of the theory. For this reason, it must have guidelines so that practicum activities can prove that the theory works well and get good results [5].

The practical guidebook was one of the media that contains activities that implement laboratory procedures so that it helps in the smooth running of the practical process. Practical guidebooks that were used are very important in an effort to determine the handling and caution in the use of chemical activities in the laboratory [6].

Books were categorized as feasible to use if they have certain aspects of the eligibility criteria. The National Education Standards Agency (BSNP) sets out 4 aspects of module feasibility, namely, the feasibility of content, the feasibility of presentation, the feasibility of language and the feasibility of the graphics issued by the Ministry of Education and Culture. In terms of content feasibility, it includes material suitability, material accuracy, and learning support material. Feasibility of presentation includes presentation techniques, learning presentation, and presentation. The feasibility of language includes the suitability of language use with the level of development of students, the use of communicative language, and the use of language to meet the requirements of the demands and integration of the flow of thinking. Feasibility of graphics includes book size, book cover design, paper quality and book content design [7]. 


\section{LITERATURE}

\section{A. Research and Development}

The research was often known as Research and Development (R \& D). Development research was a process used to develop and validate research products [8]. Development research was also defined as a systematic study to design, develop, and evaluate programs, processes and learning outcomes that must meet the criteria of consistency and effectiveness internally [1]. In the world of education, development research was a relatively new type of research [2]. Development research was research that was directed to produce products, designs, and processes.

Characteristics of development research include: (1) problems to be solved were real problem related to innovative efforts or the application of technology in learning as professional accountability and commitment to the acquisition of quality learning; (2) development of model, approaches and learning methods and learning media that support the effectiveness of student competency achievement; (3) product development process, validation carried out through expert testing and limited field trials need to be carried out so that the products produced are useful for improving the quality of learning. The process of development, validation, and field testing should be clearly described, so that it could be accounted for academically; and (4) The process of developing models, approaches, modules, methods, and learning media needs to be neatly documented and reported systematically in accordance with research rules that reflect originality [9]

Development research was not much different from other studies, the difference lies in the methodology alone. Model that were often used in development research were conceptual models and procedural models. The conceptual model was an analytical model that explains the product components that would be developed and related between the components. This model shows inter-conceptual relationships and does not show sequences in stages. The order could be started anywhere. While the procedural model was a descriptive model that describes rules or procedural steps that must be followed to produce a particular product [2].

The type of development research used in this study was the ADDIE model (Analysis, Design, Development, Implementation, and Evaluation).

\section{- ADDIE (Analysis, Design, Development, Implementation, and Evaluation).}

The ADDIE research model, this model consists of five main phases or five stages, namely: $(A)$ analysis, $(D)$ design, (D) evelopment, ( $i)$ implementation, and $(E)$ valuation. The analysis phase consists of two stages, namely the performance analysis stage and the needs analysis stage. After knowing the needs, then proceed to the second stage, namely design. The design made was expected to be able to answer whether the learning program that would be designed could solve the problem at the analysis stage. The third stage was the development stage, in this study we will develop books or learning resources that were suitable for the needs of students. The fourth stage was the implementation phase, namely the application or trial of the books / teaching materials that have been developed. The fifth stage was the stage of evaluation, assessment of books / teaching materials whether it has met the quality of a product that was valid, practical and has potential effects [10].

\section{B. Chemistry Practical Guide Book Laboratory}

Activities were used as sources of evidence in investigations and to learn how to design experiments that offer original insights into chemical phenomena. There were many useful skills that could be obtained: team work, reporting, presentation and discussion, time management, developing ways to solve problems [11]

The chemistry practical guide book was one of the media that contains activities that implement laboratory procedures so that it helps in the smooth running of the practicum process. Practical guidebooks that are used were very important in an effort to determine the handling and caution in the use of chemical activities in the laboratory. Similar to that implementation of practical activities requires a practical guide, where a practical guide is used to facilitate finding practical steps. In addition, practicum guides must also be able to develop scientific learning skills and process skills of students [5][6].

In addition, the practical guidebook aims as a guide for the management of chemical practicum activities which provides detailed guidance on best practices in purchasing, handling, storing and disposing of chemicals on a small scale. It also aims to help and encourage managerial activities in the laboratory and good safety and security practices in the laboratory [12].

So based on the explanations above the purpose and benefits of the chemistry practical guide book is to provide guidance to students in doing laboratory work, as a basis for conducting research related to the completion of studies or other research assignments. The preparation of this practical guidebook aims to facilitate students and be used for reference in practicum.

\section{Development of an Innovative Chemistry Guide}

Development research as a systematic assessment of design, development and evaluation of learning programs, processes and products that must meet the criteria of validity, practicality and effectiveness. Learning development has the following characteristics [13].

1. The problem that was to be solved was a real problem related to innovative efforts or the application of technology in learning as professional accountability and commitment to development research on learning acquisition. 
2. The development of models, approaches, and learning methods and learning media was intended to support the effectiveness of achieving student competencies.

3. The product development process, validation carried out through expert testing and limited field testing needs to be done so that the products produced are useful for improving the quality of learning. The process of development, validation, and field trials should be clearly described so that they can be accounted for academically.

The chemistry lab guide book was one of the media that contains activities that implement laboratory procedures so that it helps in the smooth running of the practicum process. Practical guidebooks that are used are very important in an effort to determine the handling and caution in the use of chemical activities in the laboratory.

The components that must exist in the practicum guide are: first, the practicum title must be brief and could be describe in general the practicum activities to be carried out. Second, the practicum objectives contain statements that will be carried out in practical activities in more detail. Third, the basic theory of material relating to practical activities. Fourth, the tools and materials used were tools that are needed in practical activities. Fifth, the work method contains the steps that must be taken in carrying out practical activities. Sixth, prelab questions contain questions that will test the preliminary ability of practicum before practicing. Seventh, practicum implementation must be in accordance with the steps specified in the guide. Eighth, general reports that must be completed by the practitioner complete the trial, ninth, discussion and suggestions are proposed related to the practical experiment [14].

Practicum chemistry guides can influence student learning outcomes, this was evidenced by the findings that can be obtained in the learning process by using a practicum because: (1) practicum guide could be read / absorbed and understood by most students; (2) practicum practicum guide could be implemented or applied in the environment where the student lives; and (3) student performance could be assessed by the chemistry teacher concerned within the assessment time limit [15].

\section{Eligibility Criteria for Books According BSNP}

The book were categorized as feasible to use if their have certain aspects of the eligibility criteria. The National Education Standards Agency (BSNP) stipulates 4 aspects of book feasibility, namely, the feasibility of content, the feasibility of presentation, the feasibility of language and the feasibility of graphics issued by the Ministry of Education and Culture. In terms of content feasibility, it includes material suitability, material accuracy, and learning support material. Feasibility of presentation includes presentation techniques, learning presentation, and presentation. The feasibility of language includes the suitability of language use with the level of development of students, the use of communicative language, and the use of language to meet the requirements of the demands and integration of the flow of thinking. Feasibility of graphics includes book size, book cover design, paper quality and book content design [7].

\section{RESEARCH AND METHODS}

Research conducted at the Agrotechnology Study Program, Faculty of Agriculture, Universitas Medan Area (UMA) and held in October 2018 - January 2019. The samples in this study were first semester students of Agrotechnology Study Program, 2 lecturers in Universitas Negeri Medan and 1 Chemistry Lecturer in study program Agrotechnology to validate innovative basic chemistry practicum guidebooks according to the KKNI curriculum with the criteria of has a minimum S-2 education.

This type of research includes research on $\mathrm{R} \& \mathrm{D}$ development by using the ADDIE model (Analysis, Design, Development, Implementation, and Evaluation). Development research was a research method used to produce certain products and test the effectiveness of these products [16]. Data collection techniques used were using questionnaires and questionnaires and the data collection instrument uses a Likert scale. The data analysis technique used is by analyzing the data obtained based on the analysis questionnaire. The rating scale used to analyze the practical guidebook is 1 to 4 with the following criteria:

TABLE 1. CRITERIA for ANALYSIS of PRACTICAL GUIDEBOOK

\begin{tabular}{|c|c|c|}
\hline No & Average & Variable criteria \\
\hline 1 & $3.26-4.00$ & Very valid \\
\hline 2 & $2.51-3.25$ & Valid \\
\hline 3 & $1.76-2,50$ & Less valid and needs to be revised \\
\hline 4 & $1.00-1.75$ & Ivalid and needs to be revised in total \\
\hline
\end{tabular}

\section{RESULT}

Before developing a basic chemistry lab guide, the analysis of the basic chemistry lab guide was used. Analysis of the chemistry practicum guidebook was conducted to determine the feasibility level of the guiding book both in terms of the feasibility of content, the feasibility of language, the feasibility of presentation and the feasibility of graphics in accordance with the modified BSNP standard. The results of the analysis of the basic chemistry practicum guidebook can be seen in Table 2 below:

TABLE 2. RESULTS OF ANALYSIS BEFORE DEVELOPED BASIC CHEMISTRY PRACTICAL GUIDEBOOKS

\begin{tabular}{|c|c|c|}
\hline No & Feasibility Standard & Average \\
\hline 1 & Content & 2.54 \\
\hline 2 & Languages & 2.50 \\
\hline 3 & Presentation & 2.56 \\
\hline 4 & Graphic & 3.60 \\
\hline \multicolumn{2}{|r|}{ Average } & 2.80 \\
\hline
\end{tabular}

Based on the results of assessment of basic chemistry practicum guides that have not been developed show average values in general which is 2.80 was categorized as valid but 
there were several parts of the practicum guide that need to be added. The same research was also conducted by other researchers that the feasibility of practicum product guides developed based on the results of expert team validation of $82.78 \%$ interpreted as valid categories and feasible to be used without revision. However, there are some inputs given by the expert validator on the guidebook used, namely: the depth of the material and practice needs to be improved, the translation of the concept needs to be deepened, and the questions need to be added to each experiment according to the stages and observations [17].

After an analysis of the basic chemical practicum guidebook used, the design was carried out and tried to develop. Deficiencies based on the results of analysis of basic chemistry practicum guidebooks were used as references in the design and development of chemistry practicum guidebooks developed. At the development stage, a basic chemistry practicum guidebook developed was based on the syllabus used.

The first step taken was to describe the indicators based on the semester learning design on the basic chemistry courses that have been prepared by the professors of basic chemistry courses. After that, practicum titles are designed which will be included in the practical guidebook to be developed. The format used in making innovative basic chemistry lab guides is the paper used in A4 size, thickness of the book 21-40 sheets, the dominant color of the guidebook is blue, the font used is "Times New Roman", and the contents of the guidebook consist of titles, objectives, theoretical reviews, tools and materials, work procedures, results and discussions, conclusions, discussions and bibliography.

Practical guidebooks that were developed innovate by including several components including: basic regulations in the laboratory, safety and security instructions in the laboratory, first aid in accidents in the laboratory, various signs / symbols that are often found in laboratories, procedures for handling waste and tools that used in the laboratory, curriculum analysis, basic practicum theory, practical activities, practicum report writing format, bibliography and periodic elements. Development of Innovative Basic Chemistry Practical Guidebook in the following Table 3:

TABLE 3. DEVELOPMENT OF INNOVATIVE BASIC CHEMISTRY PRACTICUM GUIDE BOOK

\begin{tabular}{|c|c|c|c|}
\hline No & Components & $\begin{array}{l}\text { Practical } \\
\text { Guide in Used }\end{array}$ & $\begin{array}{c}\text { Guide } \\
\text { Practicum } \\
\text { Innovation }\end{array}$ \\
\hline 1 & General guide & $\sqrt{ }$ & $\sqrt{ }$ \\
\hline 2 & Practicum Disciplinary Order & $\sqrt{ }$ & $\sqrt{ }$ \\
\hline 3 & Wok safety & $\sqrt{ }$ & $\sqrt{ }$ \\
\hline 4 & $\begin{array}{l}\text { Prevention and handling of } \\
\text { accidents }\end{array}$ & - & $\sqrt{ }$ \\
\hline 5 & Symbols in laboratory & - & $\sqrt{ }$ \\
\hline 6 & Chemical laboratory equipment & - & $\sqrt{ }$ \\
\hline 7 & $\begin{array}{l}\text { Syntax Models Problem Based } \\
\text { Learning (PBL) }\end{array}$ & - & $\sqrt{ }$ \\
\hline 8 & $\begin{array}{l}\text { Nature-based practical labs, real } \\
\text { labs and videos practicum }\end{array}$ & - & $\sqrt{ }$ \\
\hline 9 & Contents of the guide book & $\sqrt{ }$ & $\sqrt{ }$ \\
\hline
\end{tabular}

\begin{tabular}{|c|l|c|c|}
\hline 10 & Curriculum analysis & $\sqrt{ }$ & $\sqrt{ }$ \\
\hline 11 & $\begin{array}{l}\text { Format of practical report } \\
\text { writing }\end{array}$ & - & $\sqrt{ }$ \\
\hline 12 & Periodic system of elements & - & $\sqrt{ }$ \\
\hline 13 & Bibliography & - & $\sqrt{ }$ \\
\hline
\end{tabular}

The next step was the validation stage. At this stage, the innovative basic chemistry practicum guidebook developed was validated using a modified standard of National Education Standards (BSNP). In the validation phase it was used to produce teached materials that were standard and appropriate to use. The chemistry practical guide book developed was assessed based on four standards of feasibility according to the BSNP, namely the feasibility of content, language feasibility, feasibility of presentation and feasibility of graphics. The results of the assessment of innovative basic chemistry practicum guidebooks according to the BSNP by expert validators can be seen in Table 4 below:

TABLE 4. EVALUATION RESULTS INNOVATIVE BASIC CHEMISTRY PRACTICAL GUIDE BOOK ACCORDING TO BSNP BY EXPERT VALIDATORS

\begin{tabular}{|c|c|c|c|c|c|}
\hline \multirow{2}{*}{ No } & \multirow{2}{*}{$\begin{array}{l}\text { Standards } \\
\text { Feasibility }\end{array}$} & \multicolumn{3}{|c|}{$\begin{array}{c}\text { Assessment of Expert } \\
\text { Validators }\end{array}$} & \multirow{2}{*}{ Average } \\
\cline { 3 - 5 } & R1 & R2 & R3 & \\
\hline 1 & Contents & 3.77 & 3.69 & 4.00 & 3.82 \\
\hline 2 & Languages & 4.00 & 4.00 & 4.00 & 4.00 \\
\hline 3 & Presentation & 3.67 & 3.89 & 4.00 & 3.85 \\
\hline 4 & Graphic & 3.90 & 3.90 & 4.00 & 3.93 \\
\hline \multicolumn{6}{|c|}{ Book Average } \\
\hline
\end{tabular}

Based on Table 4 the results of the assessment of the basic chemistry practicum guidebook that has been developed in general shows an average value of 3.90 indicates that the book has been categorized as very valid and does not need to be revised and is very feasible to use.

The next stage was the implementation of a basic chemistry practical guidebook that has been developed. This stage was done to find out how much influence the basic chemistry practicum guidebook has been developed on the learning outcomes of the practitioner and practical skills during the practicum process. To find out the learning outcomes of the practitioner, the pretest and posttest were carried out by using 5 questions. Pretest was done to find out the initial ability of the practitioner by using the basic chemical practicum guide used. While the posttest is done after the practitioner uses a basic chemistry practical guidebook that has been developed. The results of the pretest and posttest can be seen in Table 4.4 below:

TABLE 5. DATA ON LEARNING PRETEST POSTTEST AND OUTCOMES PRACTICAL

\begin{tabular}{|c|c|c|c|c|}
\hline Test & Highest Value & Lowest Value & Average & N-gain \\
\hline Pretest & 60 & 40 & 50.33 & \multirow{2}{*}{0.65} \\
\hline Posttest & 90 & 75 & 82.00 & \\
\hline
\end{tabular}

Based on Table 5 shows that the learning outcomes using an innovative basic chemistry lab guide increase the learning outcomes of the practitioner. $\mathrm{N}$-gain value (level of understanding) of students in the practice of acid-base titration obtained by the average $\mathrm{N}$-gain of 0.65 which was categorized 
as moderate learning outcomes. The same research show student learning outcomes using a chemistry lab guide that has been developed showing good learning outcomes and fulfilling effective criteria [6].

The basic chemistry lab guide book that has been developed is tested to see how the practical skills during the lab process take place. Skills assessment is carried out using observation sheets that have been validated by expert valodators. The results of the praktikan skills assessment could be seen in the following Table 6 :

TABLE 6. PRACTICAL SKILL ASSESSMENT RESULTS

\begin{tabular}{|c|c|c|}
\hline No & Aspects Assessed & $\begin{array}{l}\text { Average } \\
\text { Value (x) }\end{array}$ \\
\hline 1 & $\begin{array}{l}\text { Enter } 10 \mathrm{~mL} \text { acetic acid solution into the measuring } \\
\text { cup correctly }\end{array}$ & 100 \\
\hline 2 & $\begin{array}{l}\text { Enter the } 10 \mathrm{~mL} \text { solution of acetic acid into } \\
\text { erlenmeyer correctly }\end{array}$ & 100 \\
\hline 3 & $\begin{array}{l}\text { Take a few drops of the PP indicator solution using } \\
\text { the dropper pipette correctly }\end{array}$ & 100 \\
\hline 4 & $\begin{array}{l}\text { Drop the PP indicator solution into Erlenmeyer } \\
\text { containing acetic acid correctly }\end{array}$ & 100 \\
\hline 5 & Install the clamp and statif correctly & 91.67 \\
\hline 6 & Pair the burette in the clamp and statif correctly & 91,67 \\
\hline 7 & $\begin{array}{l}\text { Calibrate the burette before } \mathrm{NaOH} \text { solution is } \\
\text { properly inserted }\end{array}$ & 83.33 \\
\hline 8 & Incorporate $\mathrm{NaOH}$ solution into the burette correctly & 100 \\
\hline 9 & Perform titration correctly & 75.00 \\
\hline \multicolumn{2}{|r|}{ Average Value of Class } & 93.52 \\
\hline
\end{tabular}

Based on Table 6 Based on the assessment of practical skills during the titration practice acid base, the practitioner has an average class value of 93.52 which is categorized Praktikan fish have very good skills. The same research show that chemical practicum guidebook based on science process skills has a potential effect on student chemistry student learning outcomes [10].

The last stage was the evaluation phase of the basic chemical practicum guidebook that has been developed. At this stage the book that has been developed will be assessed by the practitioner after the practitioner conducts practical activities using the practical guidebook. Assessment of practical guide books covers general aspects, aspects of language, aspects of content and aspects of physical appearance. Results of votes practical handbook coul be seen in Table 7 below:

TABLE 7. RESULTS OF VOTES PRACTICAL HANDBOOK BY PRACTICING

\begin{tabular}{|c|l|c|c|}
\hline No & Indicator & Average & Percentage \\
\hline 1 & General aspect & 3.44 & 86.11 \\
\hline 2 & Language aspect & 3.51 & 87.78 \\
\hline 3 & Content aspect & 3.42 & 85.50 \\
\hline 4 & Physical appearance & 3.72 & 93.00 \\
\hline \multicolumn{3}{|c|}{ Average } & 88.10 \\
\hline
\end{tabular}

Based on Table 7 the results of the assessment of the practical guidebook conducted by the practitioner after using a chemistry lab guide that has been developed has an average of $88.10 \%$ with a very good category. This proves that the basic chemistry practicum guidebook that has been developed can be understood and can make it easier for the practitioner to do the lab work. The same research show that student response to the practical guidebook developed on average gave a positive response [6].

\section{CONCLUSION}

Based on the results of data analysis and discussion, it could be concluded that, the basic chemistry chemistry guide book owned by the Agrotechnology Study Program, Universitas Medan Area has met BSNP standards, but there were still shortcomings in several aspects, so development needs to be done. The basic chemistry chemistry guide book developed for the Agrotechnology Study Program, University of Medan Area has met BSNP standards and was suitable for use. The learning outcomes of the practitioner after using the basic chemistry practicum guidebook increased, and the learning outcomes of the average practitioner were classified as moderate. The practical skills after using the basic chemistry practicum guidebook are categorized very well and the results of the practical guideline assessment carried out by the practitioner after using the chemistry practical guidebook that has been developed have been categorized very well.

\section{REFERENCES}

[1] Seels, B.B dan Richey, R.C., Teknologi Pembelajaran; Defenisi dan Kawasannya. Jakarta: IPTPI LPTK UNJ. 1994

[2] Setyosari, P., Metode Penelitian Pendidikan dan Pengembangan. Jakarta : Kencana Prenada Media Goup. 2012

[3] Arumsari, N., Fatmaryanti, S.D., and Kurniawan, E.S., Pengembangan Modul Berbasis Project Based Learning Untuk Mengoptimalkan Kemandirian dan Hasil Belajar Fisika Pada Siswa Kelas X SMA Negeri 1 Kutowinangun Tahun Pelajaran 2013/2014. Jurnal Radiasi, 5(1): 35 40. 2014

[4] Prayitno, M.A., Dewi, N.K., Wijayati, N., Pengembangan Modul Pembelajaran Kimia Bervisi Sets Berorientasi Chemo-Entrepreneurship (Cep) Pada Materi Larutan Asam Basa. Jurnal Inovasi Pendidikan Kimia, 10(1), 1617-1628. 2016

[5] Lubis, L.T., Silaban, R., dan Jahro, I.S., Pengembangan Penuntun Praktikum Kimia Dasar I Terintegrasi Pendekatan Inkuiri. Jurnal Pendidikan Kimia, 8(2), 20-30. 2016

[6] Hidayah, R., Sugiarto, B., Maharani, D.K., The Development Of Experimental Guidance Book Of Inorganic Chemistry With Material Safety Data Sheet. International Journal of Education and Research, 6(2), 59-62. 2018

[7] Kemendikbud., Buku Kurikulum Pendidikan Tinggi. Jakarta: Direktorat Jendral Pendidikan Tinggi. 2014

[8] Borg and Gall., Educational Research; An Introduction. Longman Inc, New York \& London, 1983.

[9] Santyasa, I. W., Metode Penelitian, Pengembangan, dan Teori Pengembangan Modul. Jakarta: Salemba Empat. 2009

[10] Zulaiha, Z., and Ibrahim, A.R., Pengembangan Buku Panduan Praktikum Kimia Hidrokarbon Berbasis Keterampilan Proses Sains di SMA, Jurnal Penelitian Pendidikan Kimia: Kajian Hasil Penelitian Pendidikan Kimia, 1(1), 87-93. 2014

[11] Reid, N and Shah, I., The Role Of Laboratory Work In University Chemistry, Chemistry Education Research and Practice, 8(2). 2007

[12] Choudhary, M.I., Instructor's Guide, Forms, And Signs Chemica Laboratory Safety And Security, The National Academies Press, United States of America. 2010

[13] Hamdani., Strategi Blajar Mengajar. Bandung: C.V Pustaka Setia. 2011

[14] Arifin, M., Strategi Belajar Mengajar. Jurusan Pendidikan Kimia FPMIPA UPI, Bandung. 2000 
[15] HAM, M., Pengembangan dan Implementasi Model Praktikum Kimia Berbasis Lingkungan TEmpat Tinggal Siswa pada SMU di Bandung. Jurnal Pengajaran MIPA, 1(6), 61-73. 2005

[16] Sugiyono., Metode Penelitian Kuantitatif, Kualitatif, dan $R \& D$. Bandung: Alfabeta. 2012

[17] Irmi, N.M., Adlim., and Rahmayani, R.F.I., Pengembangan Penuntun Praktikum Kimia Dasar II Berbasis Inkuiri Terbimbing Pada Materi Reaksi Redoks Dan Elektrokimia, Jurnal Ilmiah Mahasiswa Pendidikan Kimia, 1(2), 27-34. 2017 